\title{
WORK OVERLOAD, TURN OVER INTENTION, DAN WORK FAMILY CONFLICTS PADA PEGAWAI PERBANKAN DI SURAKARTA
}

\author{
Riska Fii Ahsani ${ }^{1}$, Sunarso ${ }^{2}$, Dorothea Ririn Indriastuti ${ }^{3}$ \\ Program Studi Manajemen Fakultas Ekonomi Universitas Slamet Riyadi Surakarta, ${ }^{1,2,3}$ \\ email : riskafii@gmail.com,sunarso66@gmail.com,indriastuti_ririn@yahoo.co.id
}

\begin{abstract}
ABSTRAK
Tulisan ini bertujuan menganalisis pengaruh kerja berlebih (work overload) terhadap keinginan keluar dari organisasi (turnover intention) pegawai bank pada kantor perbankan di Surakarta. Jam kerja yang tinggi dan ditambah dengan adanya work overload menyebabkan karyawan merasa tidak aman dan tidak nyaman terhadap keadaan pekerjaannya dan tidak memiliki kemampuan untuk menyelesaikan ketidakamanan itu sehingga mendorong seseorang untuk keluar dari pekerjaannya dan mencari pekerjaan lain yang lebih baik dari sebelumnya. Alasan terbesar yang diberikan selain dari beban kerja yang berat adalah urusan keluarga, tidak jarang para karyawan menjadi kekurangan waktu untuk bersama keluarganya. Hal ini menjadikan karyawan tersebut tidak dapat menjalankan tanggungjawabnya dalam pekerjaan dan keluarga secara seimbang sehingga mengakibatkan terjadinya work-family conflict yang akhirnya mendorong peningkatan turnover intention. Penelitian ini menggunakan 100 responden dari beberapa kantor perbankan di Surakarta. Sampel dipilih menggunakan metode purposive sampling. Hipotesis dalam penelitian ini diuji menggunakan Pemodelan Persamaan Struktural/ SEM (Structural Equation Modeling). Hasil penelitian menunjukkan bahwa work overload dapat meningkatkan turnover intention melalui work family conflict.
\end{abstract}

Kata Kunci: work overload, turnover intention, work-family conflicts, perbankan

\section{PENDAHULUAN}

Setiap perusahaan sangat mengandalkan dan sangat membutuhkan sumber daya manusia yang ideal guna membangun perusahaannya agar dapat terus berkembang menjadi perusahaan yang lebih baik dan menonjol dibandingkan perusahaan lain yang bergerak pada bidang yang sama. Untuk mencapai kinerja yang unggul dan menjadikan perusahaan berdaya saing, sumber daya manusia (karyawan) merupakan pelaku yang dominan dan sangat penting dalam rangka mendukung tujuantujuan perusahaan, namun ketika terdapat turnover karyawan dalam perusahaan akan merugikan perusahaan baik dari segi biaya dan menganggu keberlangsungan organisasi dan turnover intention merupakan prediktor terbaik untuk melihat adanya sinyal awal terjadinya turnover karyawan (Slattery, 2005; Egan et al., 2004; Wright and Bonett, 2007).

Salah satu masalah yang timbul yang berkaitan dengan sumber daya manusia adalah turnover. Karyawan yang melakukan turnover biasanya disebabkan karena adanya beban kerja yang berlebihan (work overload) sehingga menyebabkan karyawan mencari perusahaan yang lebih baik dibandingkan perusahaan sebelumnya. Lalu dengan adanya persepsi terhadap beban kerja juga membuat karyawan meningkatkan kemampuannya karena sadar dengan persaingan yang ada di lapangan pekerjaan saat ini (Du Plooy dan Roodt, 2013). Menurut Xiaoming, Ma, Chang, dan Shieh (2014), turnover berkenaan dengan lingkungan industri dan organisasi yaitu meninggalkan pekerjaan baik secara sukarela atau tanpa sadar (dikeluarkan). Turnover yang sering 
digunakan untuk mengukur masa kerja (berapa lama pekerja tetap pada pekerjaan) serta kepuasan atau ketidakpuasan kerja. Menurut Abelson (1987) turnover intention adalah keinginan individu untuk meninggalkan organisasi lain guna mencari alternatif pekerjaan lain. Keletihan yang ada pada saat bekerja sering kali membuat karyawan menjadi terbebani dengan pekerjaannya, seseorang tersebut menjadi terbebani dan menafsirkan bahwa pekerjaan yang dikerjakan berat. Karena adanya perasaan terbebani akan pekerjaannya pastinya akan ada niat untuk meninggalkan perusahaan tempat seseorang tersebut bekerja. Penyebab turnover karyawan pastinya bukan hanya beban kerja terhadap perusahaan, ketidakpuasan kerja dan lingkungan kerja yang tidak mendukung juga pasti akan mempengaruhi niat untuk meninggalkan perusahaan tersebut. Salah satu faktor yang dikemukakan oleh Allen dan Meyer (1997) yaitu faktor atribut peran dan pekerjaan meliputi tantangan pekerjaan, lingkup jabatan, pengorbanan, tingkat kesulitan dalam pekerjaan, ambiguitas peran, dan konflik peran. Hal ini merupakan beban kerja yang dirasakan, di mana membutuhkan aktivitas mental dan fisik dari karyawan. Gawron (2008) mendefinisikan beban kerja sebagai seperangkat tuntutan tugas, sebagai upaya, dan sebagai kegiatan atau prestasi. Beban dapat berupa beban fisik maupun beban mental. Beban fisik dapat dilihat dari seberapa banyak karyawan menggunakan kekuatan fisiknya, dan juga dapat berupa beban kerja mental yang dapat dilihat dari seberapa besar aktivitas mental yang dibutuhkan untuk mengingat hal-hal yang diperlukan, konsentrasi, mendeteksi permasalahan, mengatasi hal-hal yang tak terduga dan membuat keputusan dengan cepat yang berkaitan dengan pekerjaan sejauh mana tingkat keahlian dan prestasi kerja yang dimiliki individu. Sehingga dapat dikatakan bahwa suatu pekerjaan merupakan beban kerja bagi karyawannya jika memiliki beban kerja fisik maupun mental. Beban kerja yang dirasakan oleh seorang pekerja dapat menjadi faktor penekan yang menghasilkan kondisi-kondisi tertentu, sehingga menuntut manusia memberikan energi atau konsentrasi (perhatian) yang lebih harus diselesaikan dalam jangka waktu tertentu. Beban kerja yang terlalu berlebihan atau terlalu sedikit dapat menimbulkan gangguan atau penyakit akibat bekerja. Beban kerja yang berlebihan dapat menimbulkan kelelahan baik fisik maupun mental dan reaksireaksi emosional seperti sakit kepala, gangguan pencernaan dan mudah marah. Sedangkan beban kerja yang terlalu sedikit, di mana pekerjaan yang terjadi karena pengulangan gerak, akan menimbulkan rasa kebosanan (Gawron, 2008).

Setiap pekerja dapat merasakan beban kerja yang berbeda-beda, hal ini berkaitan dengan adanya perbedaan pemahaman, penghayatan, pengalaman, serta kemampuan tiap individu terhadap pekerjaannya. Hal ini tentunya berkaitan dengan munculnya turnover intention individu di mana dalam pekerjaan pastinya setiap karyawan memiliki niat untuk meninggalkan perusahaan yang disesuaikan dengan kebutuhan seseorang tersebut masing-masing (Dewi, 2013). Karena adanya beban kerja, menimbulkan suatu intensi untuk meninggalkan perusahaan, setiap orang menginginkan kenyamanan dalam pekerjaannya, apabila seseorang merasa tidak nyaman dengan suatu pekerjaannya, maka seseorang tersebut pasti akan ingin mencari pekerjaan yang lebih baik daripada sebelumnya. Xiaoming et al., (2014) dalam penelitiannya menjelaskan beban kerja memiliki efek dengan turnover intention bahwa semakin besar beban kerja maka semakin besar juga turnover intention suatu karyawan tersebut. Sebaliknya, semakin kecil beban kerja maka semakin kecil juga turnover intention pada suatu karyawan.

Setiap perusahaan membutuhkan karyawan sebagai tenaga kerja yang menjalankan setiap aktivitas yang ada dalam organisasi perusahaan. Ketika seorang karyawan merasakan tidak mampu menjaga harmonisasi antara tuntutan terhadap perusahaan yaitu bekerja dengan baik dengan masalah kehidupan pribadi, maka seorang karyawan tersebut memilih untuk mencari alternatif pekerjaan lain atau berhenti dari perusahaan dan memilih perusahaan lain yang menganggap akan pentingnya work life balance. Sementara ketika seseorang tidak mampu 
menjaga keharmonisan antara pekerjaan dan kehidupan pribadi, maka akan berdampak pada kepuasan kerja karyawan. Turnover intention erat hubungannya dengan work-family conflicts, ketika karyawan merasakan beban kerja yang berat kemudian tidak dapat mengelola kehidupan pribadinya dan muncul permasalahan keluarga, maka karyawan cenderung akan meninggalkan pekerjaan diperusahaannya.

Turnover intention terjadi di berbagai organisasi dikarenakan keinginan seseorang untuk mencari kenyamanan pada pekerjaannya. Perusahaan-perusahaan di Indonesia menghadapi masalah dalam mempertahankan karyawan yang berprestasi tinggi (top performing employees). Bahkan, masalah tersebut lebih tinggi dibanding kebanyakan negara-negara Asia Pasifik. Masalah lain yang dihadapi perusahaan-perusahaan di Indonesia adalah mempertahankan karyawan dengan keahlian khusus (critical skilled employees) dan karyawan berpotensi tinggi (high potential employee). Berdasarkan hasil survei Global Strategic Rewards (dalam Lathifah, 2008) yang dilakukan oleh Watson Wyatt, kehilangan karyawan berprestasi tinggi dan karyawan dengan keahlian khusus sudah menjadi masalah yang perlu diwaspadai oleh industri di Indonesia. Contohnya sektor migas, sudah terjadi indikasi aliran positif dari Indonesia ke luar negeri, seperti ke Arab Saudi, Malaysia, bahkan Eropa, karena tawaran paket renumerasi yang jauh lebih menarik. Sementara di Indonesia, paket remunerasinya masih dikaitkan dengan keadaan rata-rata domestik. Contoh lain yaitu di sektor perbankan, khususnya untuk tenaga dengan keahlian khusus. Hasil survei yang dilakukan sejak pertengahan tahun 2006-2007 itu menunjukkan turnover untuk posisi-posisi penting (level manajerial dan di atasnya) di industri perbankan antara 6,3\%-7,5\%. Sedangkan turnover karyawan di industri pada umumnya hanya berkisar $0,1-0,74 \%$. Kasus di Indonesia, fenomena turnover intention disadari benar oleh akademisi maupun praktisi. Setiap tahunnya ada sekitar 10-12\% karyawan yang melakukan turnover.
Banyaknya perusahaan-perusahaan baru yang didirikan, turut memberikan angin segar kepada para karyawan untuk mencoba sebuah peruntungan baru. Berkembangnya jumlah usahausaha waralaba dan bisnis online, turut mendorong tingginya intensitas turnover di sebuah perusahaan. Selain itu, tak dapat dipungkiri adanya sistem kontrak membuat karyawan mengantisipasi sedini mungkin sebelum perusahaan tersebut melakukan PHK kepada dirinya (Lathifah, 2008).

Turnover secara tidak langsung telah membuat berkurangnya tingkat produktivitas dalam sebuah perusahaan. Selain itu, perusahaan juga mengalami kerugian lain karena perlu mengeluarkan biaya tambahan dalam rangka melakukan perekrutan karyawan baru. Bahkan, beberapa manajer personalia mengalami frustrasi ketika mengetahui bahwa proses rekrutmen yang telah berhasil menjaring staf yang berkualitas pada akhirnya sia-sia karena staf yang baru direkrut tersebut memilih bekerja di perusahaan lain (Lathifah, 2008).

Di Indonesia perkiraan peningkatan turnover dihasilkan dari studi oleh Hay Group bekerja sama dengan Centre for Economics and Business Research seperti dilansir TopCareer Magazine (2013). Studi tersebut memperkirakan jumlah karyawan yang akan berhenti pada tahun 2014 dapat mencapai 161,7 juta atau meningkat $12,9 \%$ bila dibandingkan dengan tahun 2012, sedangkan di tahun 2015 turnover intention pada karyawan akan semakin meningkat hingga 13,4\%. Kawasan Asia Pasifik diperkirakan akan mengalami lonjakan terbesar dalam tingkat pergantian karyawan tahun 2014. Tingkat turnover di Asia Pasifik akan mengalami kenaikan tertinggi di seluruh dunia, yakni naik 21,5-25,5\% selama periode 2012-2018.

Turnover sering terjadi pada karyawan Bank. Pertumbuhan industri perbankan di Indonesia berkembang pesat. Menurut Michael R Tampi (2014) mengatakan bahwa turnover karyawan bank di Indonesia mencapai 15\% - 20\% per tahun. Dalam kasus lain, survei yang dilakukan oleh PwC (PriceWaterhouseCoopers) Indonesia (2014) menunjukkan bahwa tingkat turnover 
untuk karyawan mencapai $15 \%$ - 25\%. Survei yang dilakukan oleh $\mathrm{PwC}$ Indonesia menunjukkan bahwa sumber daya manusia di industri perbankan sering memindahkan perusahaan, 54\% responden pindah untuk mendapatkan manfaat yang lebih baik, sementara $37 \%$ responden mengatakan mereka mencari tempat kerja lain untuk peningkatan karir (Bisnis.com) . Topik mengenai turnover intention mendapat perhatian cukup besar dalam kajian manajemen dan keperilakuan saat ini. Terdapat berbagai macam faktor yang dapat mempengaruhi turnover intention. Dalam penelitian ini rumusan masalah terbagi menjadi tiga hal. Pertama, pengaruh work overload terhadap turnover intention. Kedua, berdasarkan dukungan empiris dan teoritis yang ada, peneliti juga tertarik untuk menguji pengaruh work-family conflicts pada turnover intention. Ketiga, penulis ingin menguji pengaruh workfamily conflicts sebagai variabel mediasi pengaruh work overload pada turnover intention.

\section{BAHAN DAN METODE}

\section{Landasan Teori}

\section{Pengaruh Work Overload terhadap Turnover Intention}

Menurut Menteri Pemberdayaan Aparatur Negara (1997), pengertian beban kerja adalah sekumpulan atau sejumlah kegiatan yang harus diselesaikan oleh suatu unit organisasi atau pemegang jabatan dalam jangka waktu tertentu. Setiap orang pernah mengalami beban kerja yang terlalu berat (work-overload) pada sesuatu waktu. Beban kerja berlebihan (work-overload) adalah suatu kondisi yang terjadi bila lingkungan memberi tuntutan melebihi kemampuan individu. Dengan demikian yang dimaksud dengan beban kerja adalah sejumlah kegiatan atau tugas-tugas yang harus diselesaikan oleh pekerja dalam jangka waktu tertentu. Sejalan dengan pernyataan tersebut Anitei, et al., (2015) mendefinisikan overload kerja sebagai interaksi antara tanggung jawab kerja aktual dengan tekanan psikologis yang berasal dari tuntutan pekerjaan. Ketegangan psikologis ini muncul ketika tuntutan pekerjaan dianggap melebihi kapasitas karyawan. Kelebihan beban kerja yang dirasakan adalah sejauh mana karyawan diminta untuk melakukan lebih banyak pekerjaan daripada tanggung jawab yang diharapkan dalam periode tertentu (Tabassum, et al., 2017). Karyawan dalam perusahaan secara konstan diminta untuk mengambil beban kerja dengan tenggang waktu yang tidak dapat diraih. Faktanya, kondisi kelebihan pekerjaan dan lebih sedikit waktu untuk menyelesaikan pekerjaan merupakan tuntutan paling umum dalam lingkungan kerja karyawan (Moore, 2000). Ahuja et al. (2007) menetapkan bahwa work overload secara signifikan mempengaruhi keseimbangan kehidupan kerja sehingga muncul niat berpindah. Salah satu alasan atau faktor yang menyebabkan turnover intention, di mana perubahan pekerjaan dapat disebabkan oleh beban kerja yang sangat berat dari perusahaan yang menciptakan tekanan kerja sehingga karyawan tidak dapat mengimplementasikannya. Bothma dan Roodt (2013) dalam penelitian mereka menyatakan bahwa work overload memiliki hubungan yang sangat kuat dan searah dengan turnover intention, yang berarti bahwa jika beban kerja semakin tinggi maka intensitas perpindahan karyawan juga akan meningkat dan sebaliknya, jika beban kerja semakin rendah maka keinginan karyawan untuk berpindah juga akan berkurang. Berdasarkan uraian penelitian sebelumnya maka dapat disimpukan hipotesis:

\section{H1: Work Overload berpengaruh positif terhadap Turnover Intention}

\section{Pengaruh Work Family Conflicts terhadap Turnover Intention}

Banyak penelitian menyimpulkan work family conflicts memiliki hubungan yang signifikan dengan turnover intention karyawan (Noor dan Maad, 2008). Keinginan yang tinggi untuk meninggalkan perusahaan akan menyebabkan lebih banyak pekerjaan 
dan ketidaksetaraan keluarga di antara karyawan (Adams et al., 1996). Work family conflicts terjadi ketika aktivitas pekerjaan mengganggu tanggung jawab individu dalam lingkungan keluarga. Misalnya, individu membawa pulang pekerjaan dan berusaha untuk menyelesaikannya dengan mengorbankan waktu keluarga (Noor, 2003). Jika individu terus menerus menghadapi bentrokan yang sedang berlangsung dan yang belum terselesaikan antara pekerjaan dan perannya dalam keluarga, seseorang akan memutuskan untuk mencari pekerjaan lain. Dengan demikian dapat memaksimalkan niat mereka untuk meninggalkan organisasi (Noor dan Maad, 2008).

Amstad, et.al., (2011) menyatakan bahwa salah satu efek work family conflicts terkait dengan pekerjaan adalah turnover intention. Hasil penelitian juga menunjukkan bahwa turnover sering terjadi karena adanya pertentangan tanggung jawab antara pekerjaan dan keluarga. work family conflicts memiliki hubungan positif dengan turnover intention (Greenhaus et al., 2006) di mana konflik dalam keluarga yang muncul dapat mempengaruhi perilaku seorang karyawan dalam bekerja seperti terlambat menyelesaikan pekerjaan dan permasalahan kehadiran. Penelitian yang dilakukan Tabassum et al., (2017) menunjukkan bahwa work family conflicts memiliki efek positif dan signifikan terhadap turnover intention.. Artinya, semakin tinggi konflik yang dirasakan seseorang, semakin tinggi keinginan orang tersebut untuk meninggalkan perusahaan sehingga dapat disimpulkan hipotesis:

$\mathrm{H} 2$ : Work family conflicts berpengaruh positif terhadap turnover intention.

\section{Pengaruh Work Overload terhadap Turnover Intention yang dimediasi oleh Work Family Conflict}

Pekerjaan yang terlalu berat dan keluarga yang terabaikan tentu merupakan masalah mendasar bagi seorang pekerja, terkadang seorang pekerja harus bekerja dari pagi hari sampai dengan larut malam sehingga mereka mengabaikan keluarga. Hal ini tentu saja menimbulkan kecemburuan dari pihak keluarga dimana mereka merasa diabaikan karena anggota keluarga tersebut terlalu fokus dan memikirkan pekerjaannya Jam kerja yang panjang dan beban kerja yang berat merupakan pertanda langsung akan terjadinya konflik pekerjaan keluarga. Konflik seperti ini pasti akan dialami oleh setiap pekerja, bagi para pekerja yang mampu menghadapi konflik ini maka mereka akan menemukan kepuasan dan kemudahan dalam bekerja karena mereka mampu mengatur dan menghadapi konflik yang mereka alami antara pekeraan dan keluarga, tetapi bagi para pekerja yang tidak mampu menghadapi konflik ini, maka ada kemungkinan mereka harus meninggalkan salah satu dari dua pilihan yaitu keluarga atau pekerjaan. Tentu saja ini merupakan pilihan yang berat karena kita harus memilih salah satu dari dua hal yang paling penting didalam hidup kita.

Menurut James L. Gibson, setiap orang pernah mengalami beban kerja yang terlalu berat (work-overload) pada sesuatu waktu. Beban kerja berlebihan (work-overload) adalah suatu kondisi yang terjadi bila lingkungan memberi tuntutan melebihi kemampuan individu. Sedangkan menurut Riggio, dalam dunia industri beban kerja yang berlebihan terjadi apabila suatu pekerjaan menuntut kecepatan kerja, hasil kerja, dan konsentrasi yang berlebihan dari karyawannya. Beban kerja berlebihan dipercaya sebagai salah satu sumber yang paling besar menyebabkan keinginan seorang karyawan untuk berpindah pekerjaan.

Keinginan berpidah dapat terjadi jika para pekerja merasa bahwa konflik dalam keluarga menghambat pekerjaan dan terlalu banyak dan beragam pekerjaan yang harus dilakukan, atau tidak cukup waktu yang tersedia untuk menyelesaikan tugas yang dibebankan. Berdasarkan uraian tersebut dapat diduga bahwa: 
H3: Work Overload berpengaruh positif terhadap Turnover Intention melalui Work family conflicts.

Work overload dapat mempengaruhi turnover intention melalui work family conflicts tercermin dalam model penelitian yang ditunjukkan Gambar 1.

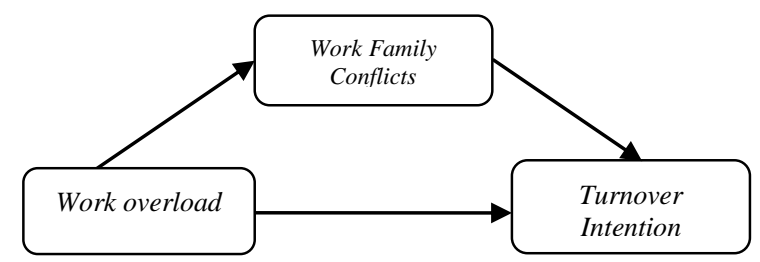

Gambar 1.

Model Penelitian

\section{Metode Penelitian}

Penelitian ini merupakan penelitian kuantitatif jenis konfirmatoris yang dapat menjelaskan hubungan korelasional antar variabel melalui pengujian hipotesis, dengan desain penelitian survei. Metode pengumpulan data menggunakan self-administered survey. Jenis data yang digunakan bersifat cross-sectional.

Pengambilan sampel pada penelitian ini melalui non-probability sampling, yaitu dengan purposive sampling. Sampel penelitian ini adalah pekerja perbankan di Kota Surakarta. Jumlah dan karakteristik karyawan memenuhi kebutuhan penelitian yaitu sebanyak 100 sampel. Pengukuran konstruk dalam penelitian ini menggunakan skala likert yang dinyatakan dengan angka 1 (sangat tidak setuju) sampai angka 5 (sangat setuju). Work Family Conflict Scale diadopsi dari Adams et al. (1996) berisi 5 item pertanyaan. dirancang untuk mengukur tingkat keparahan konflik kerja dan keluarga dan konsekuensinya pada responden. Untuk pertanyaan Work overload dikembangkan oleh Moore (2000). Work overload scale terdapat 4 item pertanyaan yang dikembangkan untuk mengidentifikasi efek dari beban kerja yang dirasakan pada turnover intention. Dan untuk turnover intention, enam pertanyaan diperoleh dari kuesioner yang dikembangkan oleh Roodt's Turnover Intention Scale (Bothma dan Roodt,
2013). Sehingga penelitian ini secara keseluruhan menggunakan lima belas item kuesioner.

\section{HASIL DAN DISKUSI}

Kuesioner sebanyak 115 telah didistribusikan oleh peneliti dan kuesioner yang bisa dikumpulkan kembali oleh peneliti adalah sejumlah 105 kuesioner (respon rate 91,30\%). Sebanyak kuesioner tidak semua data bisa dianalisis karena sebanyak 5 responden tidak mencantumkan data diri secara lengkap dan tidak memenuhi kriteria responden. Sehingga hanya ada 100 kuesioner yang dapat dianalisis lebih lanjut. Penyebaran kuesioner dilakukan dalam rentang waktu dari bulan Juli 2019 sampai dengan Agustus 2019.

Karakteristik responden untuk jenis kelamin didominasi oleh perempuan dengan presentase sebesar $63,20 \%$, pada kategori umur paling banyak adalah rentang usia 30-40 tahun dengan presentase sebesar 40,50\%, untuk kategori tingkat pendidikan yang mendominasi adalah lulusan sarjana (S1) sebanyak 75,50\% dan kategori masa kerja paling banyak adalah 2-5 tahun yaitu sebesar 43,60\%.

Hasil dari uji validitas menunjukkan semua item pertanyaan telah valid karena nilai factor loading di atas 0,5 dan memenuhi persyaratan untuk dapat diuji ke tahap selanjutnya yaitu uji reliabilitas. Dalam penelitian ini, seluruh variabel yaitu work overload, work-family conflicts, dan turnover intention dinyatakan reliabel dengan nilai CR (Conctruct Reliability) sama dengan atau di atas 0,7 .

Syarat lain yang harus dipenuhi dalam menggunakan analisis SEM yaitu normalitas data. Nilai statistik untuk menguji normalitas tersebut menggunakan $z$ value $C R$ dari nilai skewness dan kurtosis sebaran data. Nilai kritis $C R$ skewness di bawah 2 dan nilai kritis dari $C R$ kurtosis di bawah 7. 
Tabel 1.

Hasil Goodness-of-Fit Model

\begin{tabular}{llcl}
\hline $\begin{array}{l}\text { Goodness } \\
\text { of Fit } \\
\text { indeks }\end{array}$ & $\begin{array}{l}\text { Nilai yang } \\
\text { Diharapkan }\end{array}$ & Hasil & Evaluasi \\
\hline $\begin{array}{l}x^{2}- \\
\text { Chi Square }\end{array}$ & $\begin{array}{l}\text { Diharapkan } \\
\text { kecil }\end{array}$ & 20,77 & Baik \\
\hline Probabilitas & $\geqq 0,05$ & 0,054 & Baik \\
\hline CMIN/DF & $\leq 2$ & 1,733 & Baik \\
\hline$G F I$ & $\geq 0,90$ & 0,980 & Baik \\
\hline$A G F I$ & $\geq 0,90$ & 0,954 & Baik \\
\hline$T L I$ & $\geq 0,90$ & 0,985 & Baik \\
\hline$C F I$ & $\geq 0,90$ & 0,991 & Baik \\
\hline$R M S E A$ & $\leq 0,08$ & 0,050 & Baik \\
\hline \multicolumn{4}{r}{ Sumber: Data diolah (2019) }
\end{tabular}

Berdasarkan keseluruhan pengukuran goodness-of-fit model penelitian setelah proses modifikasi tersebut di atas, mengindikasikan bahwa model yang diajukan dalam penelitian ini dapat diterima.

Setelah kriteria goodness of fit model struktural yang diestimasi dapat terpenuhi, selanjutnya analisis terhadap hubungan-hubungan struktural model (pengujian hipotesis) dapat dilakukan. Dengan menggunakan analisis jalur dapat dihitung besarnya pengaruh langsung dari variabel-variabel bebas terhadap suatu variabel terikat. Hubungan antar konstruk dalam hipotesis ditunjukkan oleh regression weights.

Dari Tabel 2. terlihat bahwa nilai work overload berpengaruh terhadap work-family conflicts dengan nilai $S E 0,043$ di bawah nilai $C R 12,785$ pada probabilitas $<0,05$. Dengan hasil tersebut, dapat disimpulkan bahwa H1 didukung. Adapun pengaruh yang ditimbulkan bersifat positif. Artinya, semakin tinggi pengaruh work overload, semakin tinggi workfamily conflicts seorang karyawan dalam bekerja. Besarnya pengaruh (regression weight) adalah 0,895 menunjukkan bahwa pengaruh work overload pada work-family conflicts sangat besar karena nilainya yang mendekati angka 1 (Hair et al., 2010).
Tabel 2.

Hasil Uji Hipotesis

\begin{tabular}{|c|c|c|c|c|c|}
\hline $\begin{array}{c}\text { Regression } \\
\text { Weight }\end{array}$ & Estimate & $S E$ & $C R$ & $P$ & Ket \\
\hline $\begin{array}{l}\text { Work overload } \\
\rightarrow \\
\text { work-family } \\
\text { conflicts }\end{array}$ & ,895 & ,043 & 12,785 & ,048 & Sig \\
\hline $\begin{array}{l}\text { work-family } \\
\text { conflicts } \rightarrow \\
\text { Turnover } \\
\text { Intention }\end{array}$ & ,787 & ,056 & 17,776 & ,008 & Sig \\
\hline $\begin{array}{l}\text { Work overload } \\
\rightarrow \\
\text { Turnover } \\
\text { Intention }\end{array}$ & ,855 & ,071 & 16,495 & ,016 & Sig \\
\hline
\end{tabular}

Sumber: Data diolah (2019)

Penelitian ini membuktikan bahwa dengan adanya work overload dapat meningkatkan terjadinya work-family conflicts dalam rumah tangga karyawan. Didukungnya hipotesis ini menegaskan bahwa penelitian ini sesuai dengan penelitiann yang dikembangkan oleh Moore (2000) yang menjelaskan bahwa seseorang yang memiliki tekanan pekerjaan yang tinggi akan mengurangi waktu menjalankan peran dan tuntutan lain diluar pekerjaannya. Jam kerja yang panjang dan beban kerja yang berat akan memunculkan konflik dalam keluarga karena para pekerja tersebut tidak mampu menjalankan kewajibannya dalam keluarga.

Hasil uji hipotesis pada Tabel 2. menunjukkan bahwa work-family conflicts berpengaruh terhadap turnover intention karyawan dengan nilai $S E 0,056$ di bawah nilai $C R$ 17,776 pada probabilitas $0,008<0,05$. Dengan hasil tersebut, dapat disimpulkan bahwa $\mathbf{H 2}$ didukung. Adapun pengaruh yang ditimbulkan bersifat positif. Artinya, semakin tinggi workfamily conflicts maka turnover intention akan semakin meningkat. Besarnya pengaruh (regression weight) adalah 0,787 menunjukkan bahwa pengaruh work-family conflicts pada turnover intention sebesar 78,7\%.

Konflik yang terjadi didalam keluarga yang dipicu karena pekerjaan dikantor akan mendorong seseorang untuk keluar dari pekerjaannya. Hal ini sejalan dengan pernyataan 
Amstad, et.al., (2011). Work-family conflicts pasti dialami oleh setiap pekerja, bagi para pekerja yang mampu menghadapi konflik ini maka mereka akan menemukan kepuasan dan kemudahan dalam bekerja karena mampu mengatur dan menghadapi konflik yang mereka alami, namun bagi para pekerja yang tidak mampu menghadapi konflik, maka terdapat kemungkinan mereka harus memilih untuk meninggalkan pekerjaannya demi memenuhi peran dan tanggungjawabnya pada keluarga.

Work overload dapat meningkatkan turnover intention melalui work-family conflicts yang tertuang dalam Hipotesis 3 (H3) Didukung. Pada Tabel 2. diketahui bahwa work overload berpengaruh terhadap turnover intention karyawan dengan nilai $S E 0,071$ di bawah nilai $C R$ 16,495 pada probabilitas $<0,05$. Adapun pengaruh yang ditimbulkan bersifat positif. Artinya, semakin tinggi work overload, maka turnover intention akan semakin meningkat. Besarnya pengaruh (regression weight) adalah 0,855 menunjukkan bahwa pengaruh work overload pada turnover intention sebesar $85,5 \%$.

Frone (2003) mengatakan bahwa kehadiran salah satu peran yaitu pekerjaan akan menyebabkan kesulitan untuk memenuhi tuntutan peran yang lain seperti keluarga, dimana harapan orang lain terhadap berbagai peran yan harus dilakukan seseorang dapat menimbulkan konflik. Konflik terjadi apabila harapan peran mengakibatkan seseorang sulit membagi waktu dan sulit melaksanakan salah satu peran karena hadirnya peran yang lain kemudian menyebabkan seseorang untuk memilih keluar dari pekerjaannya. Sehingga dapat disimpulkan bahwa dengan adanya work-family conflict akan meningkatkan pengaruh work overload terhadap turnover intention.

\section{KESIMPULAN}

Work overload memiliki efek positif dan signifikan terhadap work family conflicts. Beban yang berat pada pekerja menyebabkan seseorang kehilangan peran dan dan tanggung jawab dalam keluarga sehingga dapat memicu timbulnya konflik.
Work-family conflicts memiliki efek positif dan signifikan terhadap turnover intention. Hal ini menunjukkan bahwa semakin tinggi konflik pekerjaan dengan keluarga maka semakin tinggi keinginan orang tersebut untuk meninggalkan perusahaan dan atau mencari pekerjaan lain.

Work overload berpengaruh dan searah dengan turnover intention, yang berarti bahwa jika beban kerja semakin tinggi maka intensitas untuk meninggalkan perusahaan juga akan meningkat. Keinginan berpidah dapat terjadi jika para pekerja merasa bahwa konflik dalam keluarga menghambat pekerjaan dan terlalu banyak dan beragam pekerjaan yang harus dilakukan, atau tidak cukup waktu yang tersedia untuk menyelesaikan tugas yang dibebankan.

Individu yang terus menerus menghadapi tekanan dan beban pekerjaan berat akan menimbulkan permasalahan dalam keluarga sehingga terjadi konflik. Bila hal ini terjadi maka seseorang akan cenderung memutuskan untuk keluar dari pekerjaannya dan mencari pekerjaan lain yang lebih baik.

Pada riset ini, responden melakukan self-report, sehingga sangat berpotensi menimbulkan common method bias yang disebabkan oleh bias karena sumber penilai yang sama (common rater effect bias). Pada penelitian berikutnya, dapat dilakukan berbagai cara untuk mengontrol common method bias seperti dengan langkah perbaikan prosedural maupun perbaikan statistikal. Pengumpulan data pada riset ini hanya dilakukan dengan survei melalui penyebaran kuesioner. Eksplorasi informasi responden menjadi sangat terbatas karena tidak mampu mencari keterangan lebih lanjut terhadap responden. Untuk menambahkan kekayaan informasi dan tambahan pengetahuan pada saat penyusunan hasil riset, penelitian selanjutnya dapat menggunakan metode triangulasi dengan wawancara lebih mendalam pada responden. 


\section{DAFTAR PUSTAKA}

Adams, G. A., King, L. A., and King, D. W. (1996). Relationships of job and family involvement, family social support, and work-family conflict with job and life satisfaction. Journal of Applied Psychology. 81, 411. 20

Ahuja, M. K., Chudoba, K. M., Kacmar, C. J., McKnight, D. H., and George, J. F. (2006). IT road warriors: Balancing workfamily conflict, job autonomy, and work overload to mitigate turnover intentions. MIS Quarterly, 31(1), 1-17.

Ahmed, M., Muddasar, M., and Perviaz, S. (2012). The Impact of Work-Family Conflict and Pay on Employee Job Satisfaction With the Moderating Affect of Perceived Supervisor Support in Pakistan Banking Sector. Global Journal of Management and Business Research. Volume 12 Issue 6.

Amstad, F, T., Meier, L, L., Fasel , U, Elfering, A, and Semmer, N,K. (2011). A MetaAnalysis of Work-Family Conflict and Various Outcomes With a Special Emphasis on Cross-Domain Versus Matching-Domain Relations. Journal of Occupational Health Psychology. Vol. 16, No. 2, 151-169

Aniţei, M., Chraif, M., and Ioniţă, E. (2015). Gender differences in workload and selfperceived burnout in a multinational company from Bucharest. Procedia Social and Behavioral Sciences, 187, 733737.

Bentzen, M.,Lemyre, P.M., and Kenttä, G. (2016). Development of exhaustion for high-performance coaches in association with workload and motivation: A personcentered approach. Psychology of Sport and Exercise, 22, 10-19.

Bothma, F.C. and Roodt, G. (2013). 'The validation of the turnover intention scale', SA Journal of Human Resource Management, 11(1): 507-519.
Ghozali, Imam. (2015). Aplikasi Analisis Multivariate dengan Program SEM. Semarang : Badan Penerbit Universitas Diponegoro

Greenhaus, H. J., Tammy, D. A., and Spector, P. E. (2006). Health consequences of workfamily: the dark side of the work-family interface. Research in Occupational Stress and Well-Being, 5, 61-98.

Hair, et al., (2006).Multivariate data analysis. Upper Saddle River, NJ: Pearson Education Inc.

Https://finansial.bisnis.com/read/20140515/90/2 28134/survei-sdm-perbankan-turn-overkaryawan-15-motif-utamanya-caritunjangan-lebih-menjanjikan

Moore, J. E. (2000). One road to turnover: An examination of work exhaustion in technology professionals. MIS Quarterly, 24 (1), 141-168.

Oshio, T., Inoue, A., and Tsutsumi, A. (2017). Does work to family conflict really matter for health? Cross-sectional, prospective cohort and fixed-effects analyses. Social Science \& Medicine, 175, 36-42.

Pradana, A., and Salehudin, I. (2013). Role of Work Overload toward Turnover Intention among Newly Hired Public Accountants. Presented at 8th International Conference on Business and Management Research. Seoul, South Korea.http://mpra.ub.unimuenchen.de/54342/

Sondhi, N., Chawla, D., Jain, P., and Kashyap, M. (2008). Work-exhaustion - A Consequential framework: Validating the model in the Indian context. Indian Journal of Industrial Relations, 43 (4), 547-573.

Tabassum, H., Farooq, Z., and Fatima, I. (2017). Work Family Conflict, Perceived Work Overload and Work Exhaustion in Employees of Banking Sector. Vol. 11 (1), 340-352. 